\title{
UDC 621.326
}

\section{DESIGN SOURCE ERRORS ANALYSIS IN THE ANGLE MEASURE DEVICES TO THE PRECISION ANTENNAS}

\author{
Mykhailo Palamar; Yuri Nakonetchnyi; Yuri Apostol; \\ Mykhailo Strembicky; Stepan Mashtalyar
}

\author{
Ternopil Ivan Puluj National Technical University, Ternopil, Ukraine
}

\begin{abstract}
Summary. The results of calculating the total error testing support rotation angle satellite antenna system. The analysis suggested calculating the optimum design rotation device, in which the total working angle of rotation error will not exceed 4'.
\end{abstract}

Key words: satellite antenna, azimuthal axis, angle sensor, resilient backlash, rotation angle error.

Statement of the problem, its importance. Designing high precision systems for largesized objects control designed for specified coordinates direction, tracking by given trajectories or detection of movable objects is an important problem for many branches of mechanical engineering, defense field. Particularly, this is relevant for the synthesis of the systems for superdirectional satellite antennas and satellite antenna systems control.

The important elements of such systems are devices for determination of the angular positions of antenna axes designed for precision measurement of the angles of the reflector beam directing and tracking the space objects by the antenna system. The efficiency of the entire antenna complex operation depends on the accuracy of measuring the absolute angular positions of the antenna axes position, since the angle measurement errors result in improper guidance and loss of communication with the satellite. Therefore, the task to detect and analyze the error sources in the designs of angle gage devices, as well as the units of their interfacing with the axes of antenna systems in order to minimize these errors is of great importance.

Analysis of the results and investigations of the problem. Numerous errors occurring in antenna systems and determining the total error of guidance of the electric axis of the antenna direction diagram (ADD) on the satellite are analyzed in many sources [1 - 2]. Mainly analysis of the errors of support-rotating device structures of SA (inaccuracy of the axes installation, deviation from the axes perpendicularity, deformation of SA structures under the influence of weight, etc.) is carried out.

With the development of space communication systems, radio monitoring, remote sensing of the Earth (RSE) in order to provide greater flow of information exchange, the SA designers move to higher frequency ranges from $8 \mathrm{GHz}$ to $20 \mathrm{GHz}$ (and more), and use parabolic antennas with large diameters of reflectors from 5 to $12 \mathrm{~m}$, providing the narrowing of SA direction diagram and necessity to determine the angles of the antenna beam directing to satellites with errors that do not exceed $1-2$ angular minutes. This demands the increased requirements for the accuracy of angle sensors, the use of advanced intelligent angular sensors [3-5], as well as the improvement in the interface units of angle measurement devices with antenna axes.

The objective of the paper. Analytical estimation of sources and total error of interface units of angular sensors in the structure of the support-turning platform of antenna devices in order to optimize the design and software - hardware minimization of errors of the SA pointing angle determination. 
Analysis of the errors sources and calculation of the total error for angular position measurement devices. For precision measurements of the rotation angles of antenna system with $5 \mathrm{~m}$ reflector diameter, we designed the angle measuring device including an angle sensor and interface mechanism with the antenna axis.

The device is mounted on the support-rotating antenna platform and controls the angles of each axis rotation directly to the shaft without the use of any additional mechanical gears. According to the technical requirements, the error of angles follow-up should not exceed 4 (angular minutes). The optoelectronic angular sensor, designed by PV of TNTU with the resolution of 20 angle sec., and the total error up to 2 is used in the designed device. Therefore, the total kinematic error of the mechanism of the angle sensor shaft connection with the fixed antenna case (actuator of the angle sensor) should not exceed 2.

The version of the design of the corner-shaped device with the rigid bearing shaft and two couplings for interfacing with the axis of «Crystal-5m»SA, for which the control system has been developed by us, is shown in Fig.1.

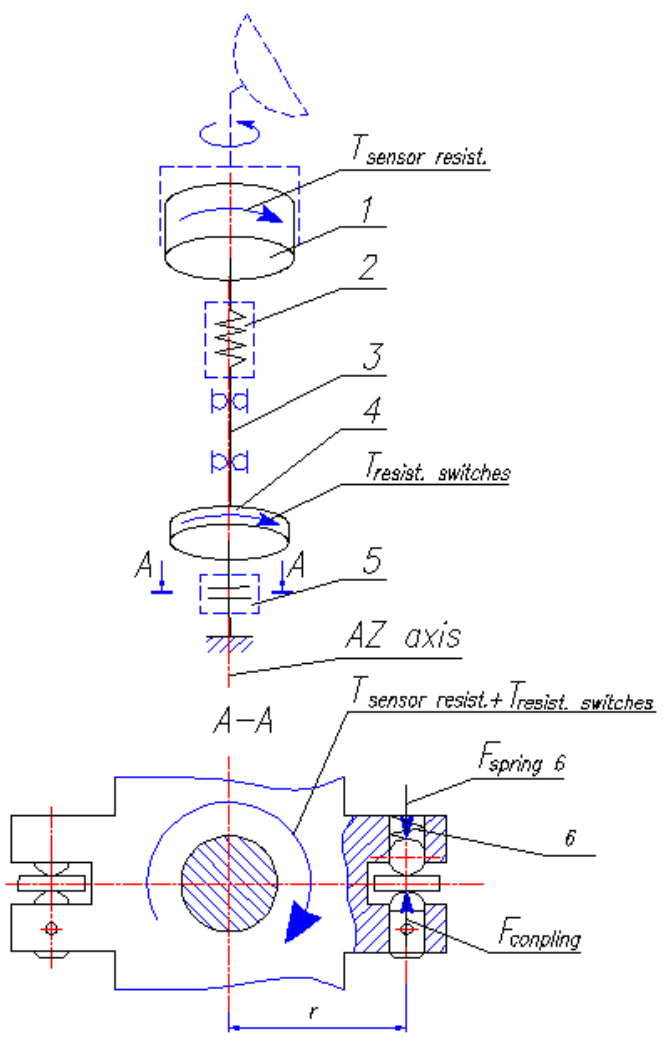

a)

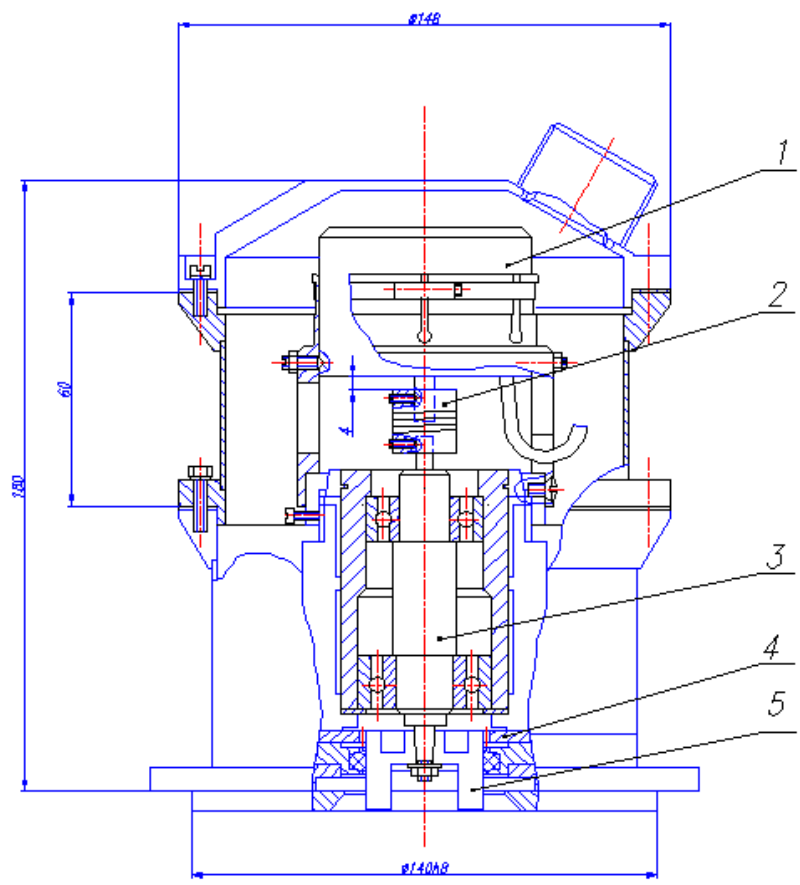

b)

Figure 1. Scheme a) and construction b) angular measuring device with a rigid shaft and a flexible coupling

The designed device consists of the optoelectronic angle sensor with built-in microcontroller for the information processing 1 (intelligent sensor) [4] elastic coupling 2 compensating possible radial and angular inequality of the sensor output shaft and the rigid bearing shaft 3 , and the hinge-cross coupling 5 . The sensor driver construction is free from slack. Kinematic errors while measuring the antenna rotation angle occur only due to elastic deformations of the coupling 2 from the action of the friction moment $T_{\text {sensor resist. }}$ in the angle sensor supports 1 and the springs deformation 6 in the hinge-cross coupling 5 from the total moment $\mathrm{T}_{\text {sensor resist. and resistance moment }} \mathrm{T}_{\text {resist.switches occurring in the final switches }}$ mechanism 4 . When the antenna is reversible, these elastic deformations are doubling. 
Results of the evaluation of errors sources of such construction version are given in Table.1. Calculations are made for two versions of the coupling 2: with elastic element in the form of spiral cylindrical threading and with ring cuts up to the half of the coupling diameter (has larger twist rigidity). It is also considered that optoelectronic angular sensors can be used in both versions: with sliding bearings and a cuff for sealing the output shaft (sealed, can be used under atmospheric conditions, it is experimentally investigated that their own resistance moment is $0.075 \mathrm{Nm}$ ) and with roller bearings (have their own moment of resistance forces $0.015 \mathrm{Nm})$.

Table 1

Calculation total error kinematic drive mechanism angular sensor with a rigid shaft and flexible coupling

\begin{tabular}{|c|c|c|c|c|c|}
\hline \multirow{4}{*}{$\begin{array}{l}\text { 1. Moment of sensor } \\
\text { resistance forces } 1 \text { (shift } \\
\text { effort) } \\
\text { 2. Hardness when } \\
\text { twisting elastic coupling }\end{array}$} & \multirow{4}{*}{$\begin{array}{l}T_{\text {sensor resist. }} \\
\\
\text { Celastic coup. }\end{array}$} & \multirow{2}{*}{\multicolumn{2}{|c|}{$\begin{array}{c}\text { With sliding } \\
\text { sleeves and seals } \\
0,075 \mathrm{Nm}\end{array}$}} & \multirow{2}{*}{\multicolumn{2}{|c|}{$\begin{array}{c}\begin{array}{c}\text { With rolling } \\
\text { bearings }\end{array} \\
0,015 \mathrm{Nm}\end{array}$}} \\
\hline & & & & & \\
\hline & & 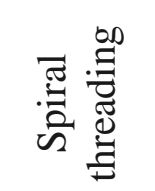 & $\begin{array}{l}\stackrel{\infty}{\Xi} \\
00 \\
\Xi \\
0\end{array}$ & 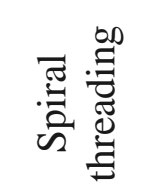 & 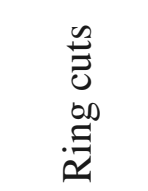 \\
\hline & & $\begin{array}{c}40 \\
\mathrm{Nm} / \mathrm{rad}\end{array}$ & $\begin{array}{c}250 \\
\mathrm{Nm} / \mathrm{rad}\end{array}$ & $\begin{array}{c}40 \\
\mathrm{Nm} / \mathrm{rad}\end{array}$ & $\begin{array}{c}250 \\
\mathrm{Nm} / \mathrm{rad}\end{array}$ \\
\hline $\begin{array}{l}\text { 3. Strength of spring } 6 \text { of } \\
\text { cross coupling } 5\end{array}$ & $F_{\text {spring } 6}$ & \multicolumn{4}{|c|}{$10 \mathrm{~N}$} \\
\hline $\begin{array}{l}\text { 4. Arm } \mathrm{r} \text { of the cross } \\
\text { coupling } 5\end{array}$ & $r$ & \multicolumn{4}{|c|}{$14 \mathrm{~mm}$} \\
\hline $\begin{array}{l}\text { 5. Moment of resistance } \\
\text { forces of the final } \\
\text { switches mechanism } 4\end{array}$ & $T_{\text {resist. switches }}$ & \multicolumn{4}{|c|}{$0,075 \mathrm{Nm}$} \\
\hline $\begin{array}{l}\text { 6. The minimum } \\
\text { required force of the } \\
\text { spring } 6 \text { when } \\
\text { transmitted by the cross } \\
\text { coupling } 5 \text { of the torque } \\
T_{\text {sensor resist. }}+T_{\text {resist. switches }}\end{array}$ & $\begin{array}{c}F_{\text {coupling }}= \\
=\frac{T_{\text {sensor resist. }}}{2 r}+ \\
+\frac{T_{\text {resist.switches }}}{2 r}\end{array}$ & \multicolumn{4}{|c|}{$\begin{array}{r}\left(F_{\text {coupling }}<F_{\text {spring }}\right. \\
\text { deformation } 6 \text { and th } \\
\text { of the coupling } 5\end{array}$} \\
\hline $\begin{array}{l}\text { 7. Twisting angle of the } \\
\text { elastic coupling } 2\end{array}$ & $\begin{array}{l}\varphi_{\text {elastic coup. }}= \\
=\frac{T_{\text {sensor resist. }} .}{C_{\text {elastic coup. }}}\end{array}$ & $6,4^{\prime}$ & $1,03^{\prime}$ & $1,2^{\prime}$ & $0,2^{\prime}$ \\
\hline $\begin{array}{l}\text { 8. Elastic dead stroke } \\
\text { during reverse } \\
\text { movement }\end{array}$ & $\begin{array}{c}\Delta_{\text {d.stroke }}= \\
=2 \varphi_{\text {elastic coup } .}\end{array}$ & $12,9^{\prime}$ & $2^{\prime}$ & $2,4^{\prime}$ & $0,4^{\prime}$ \\
\hline
\end{tabular}


The version of the angle gage device design with long thin shaft and rigid coupling is shown in Fig. 2.
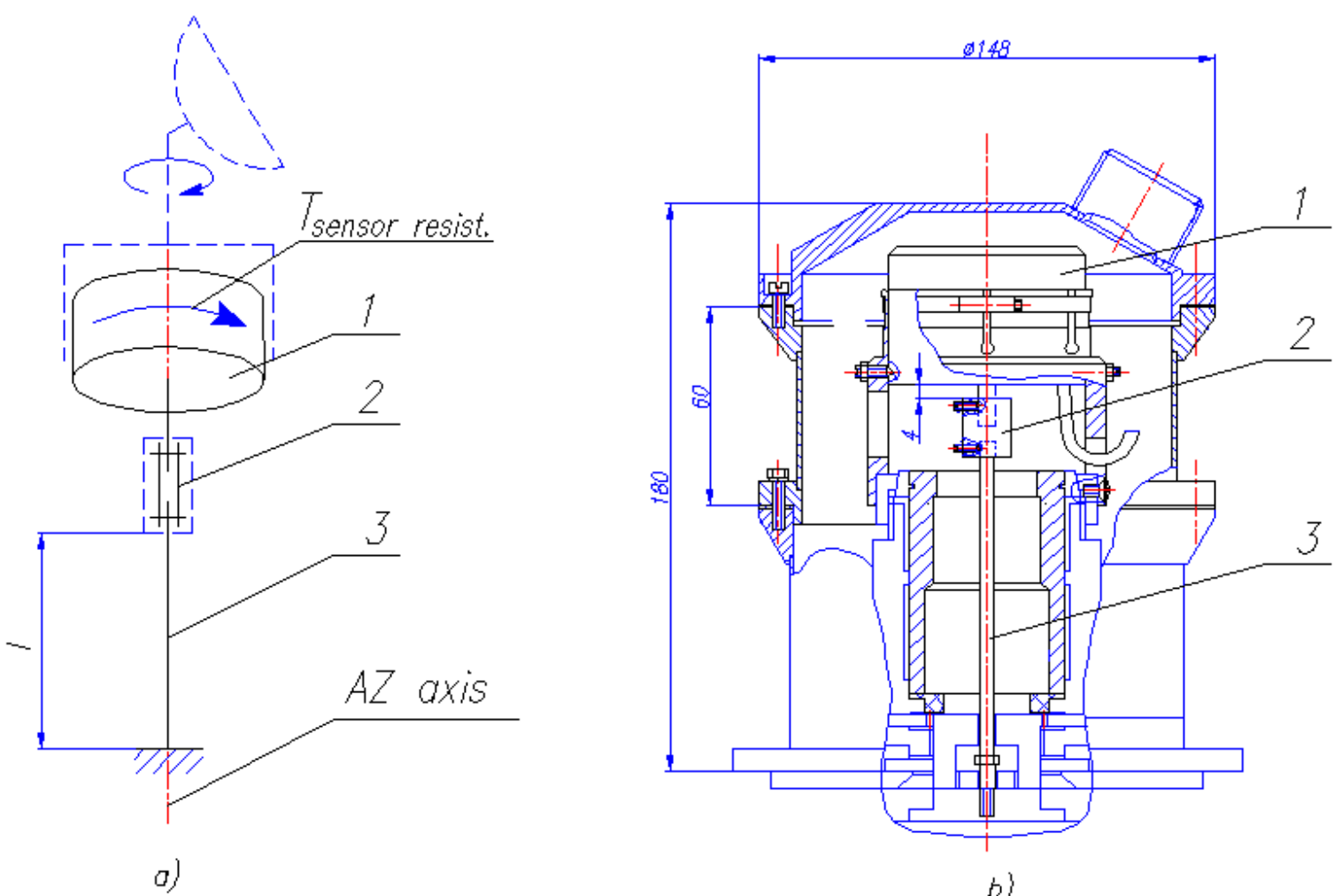

b)

Figure 2. Scheme a) and construction b) angular measuring device with a thin Hučko shaft and deaf coupling

The peculiarity of this construction is that the shaft of the sensor 1 through the rigid coupling 2 and the thin steel shaft 3 with diameter $d=6 \mathrm{~mm}$ and operating length $1=107 \mathrm{~mm}$ direction is directly connected to the antenna body. There are no gaps in the connection. The permanent cross coupling (not shown in Fig. 2) connects to the fixed antenna case only final switches mechanism and is not affected by its error on the dead stroke of the sensor drive. The deformation of the fixed coupling 2 and the output shaft of the sensor are neglected. The possible inequality of the sensor shaft 1 and shaft 3 is compensated due to the elastic deformations of the thin, and, therefore, relatively flexible shaft 3. Unfortunately, the twisting

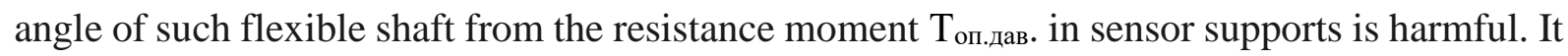
will create the kinematic error in this design version of the angle gage device when measuring the antenna rotation angle. 


\section{Table 2}

Calculation of total kinematic error Azimuth device with a thin flexible shaft coupling and deaf

\begin{tabular}{|c|c|c|c|}
\hline $\begin{array}{l}\text { 1. Resistance forces moment of } \\
\text { the angle sensor } 1\end{array}$ & $T_{\text {sensor resist. }}$ & $\begin{array}{c}\text { With slide } \\
\text { bushings slip and } \\
\text { seals }\end{array}$ & $\begin{array}{l}\text { With roller } \\
\text { bearings }\end{array}$ \\
\hline & & $0,075 \mathrm{Nm}$ & $0,015 \mathrm{Nm}$ \\
\hline $\begin{array}{l}\text { 2. Length } 1 \text { and diameter } d \text { of } \\
\text { the steel shaft } 3\end{array}$ & $\begin{array}{l}l \\
d\end{array}$ & \multicolumn{2}{|c|}{$\begin{array}{l}\mathrm{l}=107 \mathrm{~mm} ; \\
\mathrm{d}=6 \mathrm{~mm}\end{array}$} \\
\hline $\begin{array}{l}\text { 3. Modulus of elasticity at } \\
\text { torsion }\end{array}$ & $G$ & \multicolumn{2}{|c|}{$8 \times 10^{4} \mathrm{MPa}$} \\
\hline $\begin{array}{l}\text { 4. Polar moment of inertia of } \\
\text { the shaft } 3 \text { cross-section }\end{array}$ & $I_{p}=\frac{\pi \cdot d^{4}}{32}$ & \multicolumn{2}{|c|}{$127,17 \mathrm{~mm}^{4}$} \\
\hline 5. Torsion angle of shaft 3 & $\begin{array}{c}\varphi= \\
=\frac{T_{\text {sensor resist. }} \cdot l}{G \cdot I_{p}}\end{array}$ & $\begin{array}{c}2,75^{\prime} \\
(0,0008 \mathrm{rad})\end{array}$ & $\begin{array}{c}0,54^{\prime} \\
(0,00016 \mathrm{rad})\end{array}$ \\
\hline $\begin{array}{l}\text { 6. Elastic dead stroke at reverse } \\
\text { motion }\end{array}$ & $\Delta_{\text {d.stroke }}=2 \varphi$ & $5,5^{\prime}$ & $1,08^{\prime}$ \\
\hline
\end{tabular}

Conclusion. The total error of the rotation angle follow-up in the angular gage device do not exceed 4' only in the following cases: for the construction version shown in Fig. 1 - in case the elastic coupling 2 with ring cuts is used, and the springs 6 loading should be not less than 5,36 N; for the construction version shown in Fig.2 - in case the angle sensor with roller bearings is used.

\section{References}

1. Belianskyi P.V. Upravlenye nazemnumy antennamy y radyoteleskopamy [Tekst], P.V. Belianskyi, B.H. Serheev, M.: Sov. Radyo, 1980, 280 p. [In Russsian].

2. Bydiuk P.Y., Marosyn O.P., Danylchuk S.H., Selyn A.N. Systema adaptyvnoho upravlenyia dlia klassa raspredelennukh mekhanycheskykh system, 4 NTK «Problemu kompleksnoi avtomatyzatsyy»: Tez. Dokl.Kyev: Yn-t kybernetyky AN Ukraynd, 1990, Vol. 2, p. 32 - 36 [In Ukrainian].

3. Gerard C.M. Meijer. Smart Sensors Systems. John Wiley\&Sons, Ltd, 2008. 404 p.

4. Mykhaylo Palamar Improvement Metrological Characteristics of the Antenna System Using Smart Angle Sensor [Text] / Mykhaylo Palamar, Andrii Chaikovskyi, Yuriy Pasternak, Yaroslav Palamar // Proceedings of the 2015 IEEE 8th International Conference on Intelligent Data Acquisition and Advanced Computing Systems: Technology and Applications (IDAACS): 24 - 26 September 2015, Warsaw, Poland. IEEE, P.: 131 - 135. ISBN: 978-1-4673-8359-2, IEEE Catalog Number: CFP15803-PRT. https://doi.org/ 10.1109/IDAACS.2015.7340713

5. Theory of information (information-measuring systems, errors, identification). / P.D. Stukhliak, A.V. Buketov, M.A. Dolhov, O.V. Ivanchenko. - Kherson: Aylant, 2011. - 371 c.

\section{Список використаної літератури}

1. Белянский, П.В. Управление наземными антеннами и радиотелескопами [Текст] / П.В. Белянский, Б.Г. Сергеев. - М.: Сов. радио, 1980. - 280 с. 
2. Система адаптивного управления для класса распределенных механических систем [Текст]/ П.И. Бидюк, О.П. Маросин, С.Г. Данильчук, А.Н. Селин // 4-я НТК «Проблемы комплексной автоматизации»: Тез. Докл. - Киев: Ин-т кибернетики АН Украины, 1990. - Ч. 2. - С. 32 - 36.

3. Gerard C.M. Meijer. Smart Sensors Systems. John Wiley\&Sons, Ltd, 2008. - 404 p.

4. Mykhaylo Palamar Improvement Metrological Characteristics of the Antenna System Using Smart Angle Sensor [Text] / Mykhaylo Palamar, Andrii Chaikovskyi, Yuriy Pasternak, Yaroslav Palamar // Proceedings of the 2015 IEEE 8th International Conference on Intelligent Data Acquisition and Advanced Computing Systems: Technology and Applications (IDAACS): 24 - 26 September 2015, Warsaw, Poland. IEEE, P.: 131 - 135. ISBN: 978-1-4673-8359-2, IEEE Catalog Number: CFP15803-PRT. https://doi.org/ 10.1109/IDAACS.2015.7340713

5. Теорія інформації (інформаційно-вимірювальні системи, похибки, ідентифікація) [Текст]/ П.Д. Стухляк, А.В. Букетов, М.А. Іванченко. - Херсон, Айлант. - 2011. - 371 с.

\title{
УДК 621.326
}

\section{АНАЛІЗ ДЖЕРЕЛ ПОХИБОК КОНСТРУКЦЙ КУТОВИХ ВИМІРЮВАЛЬНИХ ПРИСТРӦ̈В У ВИСОКОТОЧНИХ АНТЕНАХ}

\section{Михайло Паламар; Юрій Наконечний; Юрій Апостол; Михайло Стрембіцький; Степан Машталяр}

\author{
Тернопільський нащіональний технічний університет імені Івана Пулюя, \\ Тернопіль, Україна
}

\begin{abstract}
Резюме. Наведено результати аналітичного очінювання джерел похибок та розрахунок сумарної похибки відпрацювання кута повороту різними конструкціями кутових вимірювальних пристроїв супутникових антен. Проаналізовано конструкиї з жорстким валом на підшипниках кочення $i$ двома компенсуючими муфтами та конструкиії з тонким гнучким валом і однією глухою беззазорною муфтою. Представлені результати розрахунків свідчать, щз мінімальної похибки (до двох кутових мінут) вузлів спряження кутових сенсорів з осями антени можна досягти в першому випадку (конструкція з жорстким валом на кулькових підшипниках) тільки при застосуванні кутових сенсорів з підшипниками кочення та пружної муфти з кільцевими надрізами, яка має більшу крутильну жорсткість. А в другому випадку (конструкція з тонким гнучким валом і глухою беззазорною муфтою) - при застосуванні кутових сенсорів з підшипниками кочення. Враховуючи, щео варіант кутомірного пристрою з гнучким валом має простішу конструкиію і меншу кількість вузлів, щзо можуть бути потенційним джерелом похибок відпрацювання кута повороту (наприклад, відсутня шарнірно-хрестова муфта, а замість пружної муфти на вихідному валу сенсора застосована беззазорна глуха), иьому варіанту слід надавати перевагу. В дослідженні оцінювались тільки похибки вузлів спряження вихідних валів кутових сенсорів з осями антени. Похибки самих кутових сенсорів при розрахунку сумарної похибки кутомірних пристроїв приймались однаковими, тому щзо у всіх розглянутих конструкціях застосовувалися розроблені на кафедрі ПВ ТНТУ оптоелектронні кутові сенсори із загальною похибкою, щзо не перевищує двох кутових мінут. На основі аналізу розрахунку запропоновано оптимальну конструкиію кутомірного пристрою, в якій сумарна похибка відпрацювання кута повороту не буде перевищувати 4' (кутових мінут).
\end{abstract}

Ключові слова: супутникова антена, азимутальна вісь, давач кута, пружний мертвий хід, похибка кута повороту. 